\title{
Is it essential to perform preoperative diagnostic curettage in patients scheduled for uterine myoma surgery?
}

\author{
Ayse Ender Yumru, ${ }^{1}$ Burcu Dincgez, ${ }^{1}$ Fatih Dogru, ${ }^{1}$ Banu Ondes, ${ }^{1}$ Murat Bozkurt ${ }^{1}$ \\ Cengiz Yumru ${ }^{2}$
}

Keywords: Leiomyoma, fibroids; uterine, dilatation and curettage, hysterectomy, uterine neoplasms

\begin{abstract}
Objective: Uterine myoma, which arises from the myometrium of uterus, is among the most common benign tumors of women. Generally, it has an asymptomatic character, however, in symptomatic cases, it presents with abnormal uterine bleeding. The objective of this study is to determine whether preoperative diagnostic curettage is essential or not by comparing the preoperative and postoperative endometriums of patients that underwent surgery with uterine myoma diagnosis.
\end{abstract}

Material and Method: In this study,260 patients that received surgery with uterine myoma diagnosis in the Gynecology and Obstetrics Department of Taksim Education and Research Hospital in Istanbul between January 2007 and January 2010, were included. The histopathologic analysis of specimens obtained by preoperative curettage and hysterectomy, was carried out in a retrospective fashion.

Results: The mean age of patients was $48.3 \pm$ 7.5 years. The distribution of preoperative curettage specimens with regard to endometrial status was as follows: phase compatible endometrium in 156 (60\%), endometrial polyp in 74 (28.5\%), atrophic endometrium in 20 (7.7\%), and endometrial hyperplasia in 10 patients (3.8\%). Among the phase compatible endometriums, 85 patients (54.5\%) had proliferative endometrium, 39 patients (25\%) had late secretory phase endometrium, and 32 patients $(20.5 \%)$ had early secretory phase endometrium. The distribution of postoperative hysterectomy specimens with regard to endometrial status was as follows: Phase compatible endometrium in 160 patients (61.5\%), endometrial polyp in 61 patients $(22.5 \%)$, endometrial hyperplasia in 14 patients (5.4\%), and atrophic endometrium in 25 patients (9.6\%). Among the phase compatible endometriums; 96 patients (60\%) had proliferative endometrium, 44 patients (27.5\%) had late secretory endometrium, and 20 patients (12.5\%) had early secretory endometrium.

Conclusion: No difference was observed between the histopathologic results of diagnostic curettage and hysterectomy relative to malignancy or a pathology that would change the surgery plan. The result is very important because it shows that performing curettage before myoma surgery is not an essential procedure. In this study, since endometrial cancer may not have been detected due to limited number of patients, further studies including higher number of patients are required to confirm our results.

${ }^{1}$ Taksim Education and Research Hospital, Department of Obstetrics and Gynecology, Istanbul, Turkey

${ }^{2}$ Taksim Education and Research Hospital, Department of Anesthesiology and Critical Care, Istanbul, Turkey

Please cite this paper as: Yumru AE, Dincgez B, Dogru F, Ondes B, Bozkurt M, Yumru C. Is it essential to perform preoperative diagnostic curettage in patients scheduled for uterine myoma surgery. Proc Obstet Gynecol. 2013;3(2); Article 11 [ 8 p.]. Available from: http://ir.uiowa.edu/pog/. Free full text article.

Corresponding author: Murat BOZKURT, MD. Ismetpaşa cad. Cemal Gürsel Mah. Sefa Apt. No:113/26 44000 MALATYA /TURKEY. Tel: 904222382828/1546- 905322279072. Fax: 904222382600. e-mail jindrmb@yahoo.com

This is an Open Access article distributed under the terms of the Creative Commons Attribution 3.0 Unported License ( http://creativecommons.org/licenses/by/3.0), which permits unrestricted use, distribution, and reproduction in any medium, provided the original work is properly cited. 


\section{Introduction}

Uterine myoma is the proliferation of smooth muscle cells in myometrium which is known to be the most common pelvic tumor seen in women above 35 years of age. ${ }^{1,2}$ The yearly incidence of uterine myoma (also called as fibromyoma, fibroma, fibroid, leiomyoma, myoma, and leiomyofibroma) is $12.8 / 1000$ among women aged 25-44 years. ${ }^{3}$ However, it is not easy to determine the actual incidence of uterine myoma cases because of their generally asymptomatic course. Some studies report the myoma incidence among women as $50 \%{ }^{4}$ When the entire hysterectomy specimens are included in this evaluation, this rate rises to $77 \% .{ }^{5}$ Major risk factors of myoma development are early menarche, low parity, childbirth at young age, infertility, and starting oral contraceptives early. Many studies have shown that estrogen has a role in leiomyoma growth. ${ }^{6}$ In leiomyomas, the number of estrogen receptors and the expression of genes involved in the production of estrogen regulators such as connexin 43 gap-junction protein, Type I and III collagens, insulin-like growth factor-1, and parathyroid hormone-like peptide are observed to increase..$^{7-11}$ Moreover, P450 enzyme system contributes to the growth of leiomyomas and estrogen elevates the mitogenic activity. ${ }^{12,13}$ Although uterine myomas develop under the influence of estrogen, the association between myoma and endometrial hyperplasia or endometrial carcinoma is not high. However, many gynecologists employ preoperative endometrial biopsy on a routine basis in cases diagnosed with uterine myoma and scheduled for hysterectomy in order to detect an endometrial hyperplasia or an endometrial

adenocarcinoma beforehand. ${ }^{6,14}$ In our study, we aimed to determine whether preoperative diagnostic curettage is essential by comparing the histopathologic findings obtained before and after hysterectomy in patients diagnosed with uterine myoma.

\section{Material and Method}

In this study, 260 patients who presented to the Gynecology and Obstetrics Department of Taksim Education and Research Hospital in Istanbul between January 2007 and January 2010, and received preoperative diagnostic curettage before undergoing surgery with diagnosis of uterine myoma, were included. The characteristics of the patients such as age, presenting symptoms, pre- and post-menopausal state, and the histopathologic findings of preoperative endometrial curettage and hysterectomy were retrospectively evaluated. In our department, the routine diagnostic curettage procedure includes dilatation of cervix with a Hegar dilator, ensued by application of curettage with a sharp curette after which obtained specimens are sent for histopathologic analysis. In cases where we fail to achieve dilatation by local anesthesia, general anesthesia is applied within operating room conditions. Patients receive hysterectomy after the curettage and the acquired hysterectomy specimen is prepared by paraffin method for macroscopic and microscopic histopathologic examination. In this study, we preferred to use descriptive statistics for the evaluation of study data. 


\section{Results}

The mean age of study population was $48.3 \pm 7.5$ years. The youngest patient was 35 years of age and the oldest was 57 years of age. The presenting complaint was menometrorrhagia in $73 \%$ (193 patients), menorrhagia in $12.4 \%$ (32 patients), pelvic pain in $10 \%$ (26 patients), urinary symptoms in 3\% (8 patients), and postmenopausal hemorrhage in $1.6 \%$ (4 patients) of the patients. Patients who had not experienced menstruation at least for 1 year, were deemed as menopause cases without checking the hormone profile. Thus, $85 \%$ of the study population (221 patients) were found to be premenopausal and $15 \% \quad(39$ patients) were found to be postmenopausal patients.

Histopathologic analysis of preoperative curettage specimens showed phase compatible endometrium in $156(60 \%)$, endometrial polyp in $74(28.5 \%)$, atrophic endometrium in $20(7.7 \%)$, and endometrial hyperplasia in 10 (3.8\%) patients (Graphic 1).

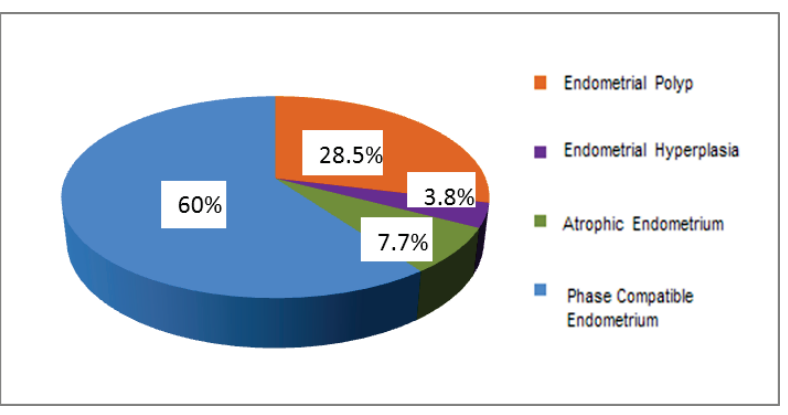

Graphic 1. Distribution of patients relative to diagnostic curettage results

Among the phase compatible endometriums; $85 \quad(54.5 \%)$ were proliferative endometrium, $39 \quad(25 \%)$ were late secretory phase endometrium, and $32(20.5 \%)$ were early secretory phase endometrium (Graphic 2).

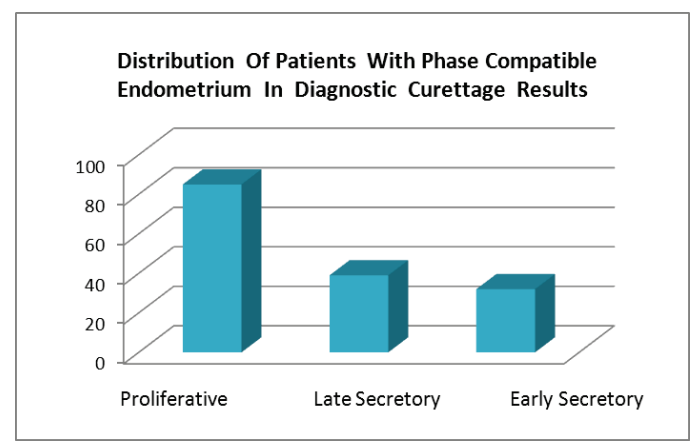

Graphic 2. Distribution of patients with phase compatible endometrium in diagnostic curettage results

Postoperative analysis of the hysterectomy specimens revealed phase compatible endometrium in 160 $(61.5 \%)$, endometrial polyp in 61 $(23.5 \%)$, atrophic endometrium in 25 $(9.6 \%)$, and endometrial hyperplasia in $14(5.4 \%)$ patients (Graphic 3).

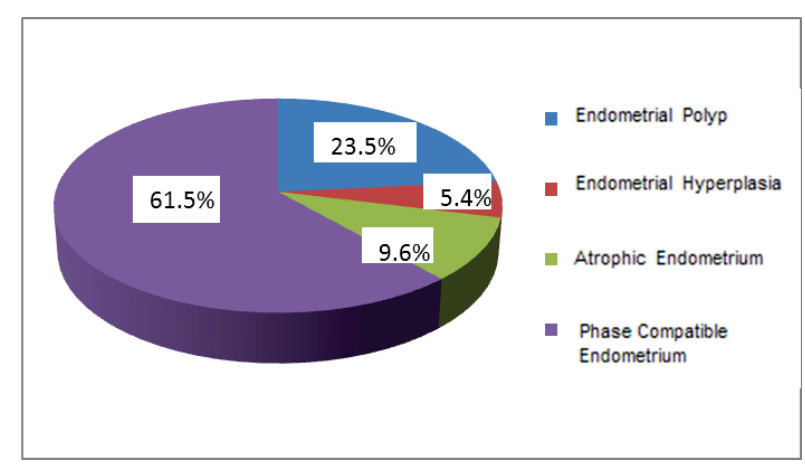

Graphic 3. Distribution of patients relative to hysterectomy results

Among the phase compatible endometriums; $96 \quad(60 \%)$ were proliferative endometrium, 44 (27.5\%) were late secretory phase endometrium, and $20(12.5 \%)$ were early secretory phase endometrium (Graphic 4). 


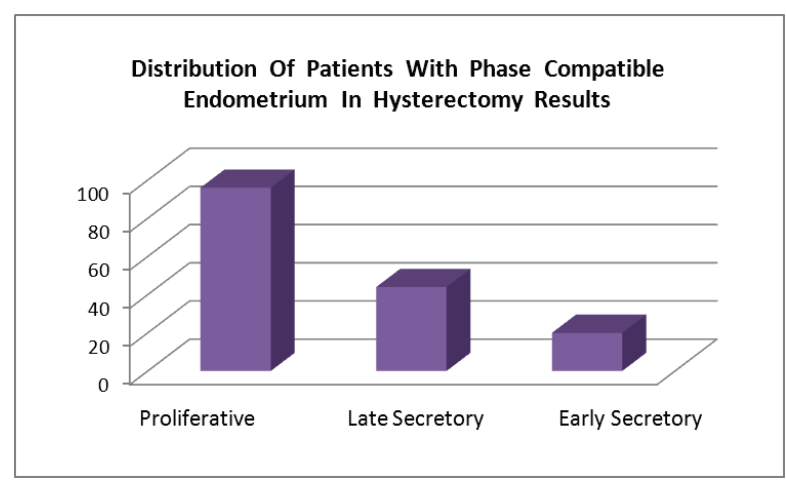

Graphic 4. Distribution of patients with phase compatible endometrium in hysterectomy results

Comparison of the histopathologic results of diagnostic curettage and hysterectomy with regard to endometrial status is shown in Table 1.

Table 1. Comparison of the histopathologic results of diagnostic curettage and hysterectomy with regard to endometrial status

\begin{tabular}{|l|r|r|}
\hline $\begin{array}{l}\text { Pathology } \\
\text { Result }\end{array}$ & $\begin{array}{l}\text { Diagnostic } \\
\text { Curettage } \\
\text { Result (n) }\end{array}$ & $\begin{array}{l}\text { Hysterectomy } \\
\text { Result (n) }\end{array}$ \\
\hline $\begin{array}{l}\text { Phase } \\
\text { compatible } \\
\text { endometrium }\end{array}$ & 156 & 160 \\
\hline Polyp & 74 & 61 \\
\hline $\begin{array}{l}\text { Atrophic } \\
\text { endometrium }\end{array}$ & 20 & 25 \\
\hline Hyperplasia & 10 & 14 \\
\hline
\end{tabular}

Histopathologic results of the diagnostic curettage specimens showed that uterine myoma and endometrial hyperplasia were both present in 3.8\% of the cases (10/260), whereas histopathologic results of the hysterectomy specimens showed that the combination of uterine myoma + endometrial hyperplasia was present in $5.3 \%$ of the patients $(14 / 260)$. Accuracy of diagnostic curettage was $97.5 \%$ in the phase compatible endometrium group, $80 \%$ in the atrophic endometrium group, and $71.4 \%$ in the hyperplasia group. The number of polyps was lower because of examining hysterectomy specimens after full curettage. In our study, when endometrial histopathologic results of diagnostic curettage and hysterectomy groups were compared relative to diagnostic accuracy, no statistically significant difference was observed $(p>0.05)$.

\section{Discussion}

Besides being the most common cause of hysterectomy, uterine myomas are also the most often seen pelvic tumor in women. ${ }^{1,2}$ Although leiomyomas are encountered very rarely during the prepubertal age, they become symptomatic particularly at $30-40$ year age group. ${ }^{15}$ In the current study, the mean age of patients was $48.3 \pm 7.5$ years. Since we included only uterine myoma cases that received hysterectomy, the age of presentation was thought to be higher than the actual value.

While most of the myomas are asymptomatic and of small size, many women experience serious problems during certain periods of their lives and require treatment. These symptoms vary depending on the number, size, localization, and degenerative character of the myomas. Abnormal uterine hemorrhage is the most common presenting symptom. The underlying causes of this hemorrhage are thought to be increased endometrial surface area and changes in myometrial blood flow associated with the stasis arising from compression or reduced uterine contractility due to presence of a mass leading to inadequate contraction of the 
uterine vessels during menstruation. ${ }^{16}$ In the current study, the presenting symptom was menometrorrhagia in $73 \%$ (190 patients) and menorrhagia in $12.4 \%$ (32 patients) of the patients. Moreover, the presenting symptom was pelvic pain in $10 \%$ (26 patients) of our patients. Myomas rarely present solely with pain. Large myomas may apply compression over the adjacent organs, leading to a chronic and blunt pain. In addition, a myoma with an intramural location can cause dysmenorrhea. Compression-related symptoms may be originating from a compression over the adjacent organs such as rectum and bladder. Myomas leading to compression over the bladder may cause incontinence; for example, 3\% (8 patients) of our patients had incontinence. $1.6 \%$ (4 patients) of our study population presented to our hospital because of postmenopausal hemorrhage. Those patients demonstrated both myoma and endometrial hyperplasia in the histopathologic analysis of curettage specimens.

Many studies have shown that estrogen plays a role in the growth of leiomyomas. ${ }^{6}$ Leiomyoma cases exhibit increased number of estrogen receptors as well as elevated expression of genes responsible for estrogen regulators such as connexin 43 gap-junction protein, type I and 3 collagen, insulin-like growth factor 1, and parathyroid hormone-like peptide..$^{7-11}$ Moreover, P450 enzyme system, which enables estrogen synthesis from androgen, also contributes to the growth of leiomyomas, and estrogen increases the mitogenic activity. ${ }^{12,13}$ Although uterine myomas develop under the influence of estrogen, they are not frequently seen in combination with endometrial hyperplasia or carcinomas. Nonetheless, although endometrial biopsy in patients scheduled for hysterectomy due to uterine myoma, is still a method that a majority of gynecologists cannot give up, the efficacy of diagnostic curettage in showing intrauterine pathologies has attracted more doubts., ${ }^{6,14}$ Epstein et al. found the misdiagnosis rate with regard to curettage findings as $58 \%$ for endometrial polyps, $50 \%$ for hyperplasias, and $11 \%$ for endometrial cancer. ${ }^{18}$ In the study of Hakverdi et al., diagnostic accuracy rate was $52 \%$ for atrophic endometrium, $47 \%$ for simple hyperplasia, $100 \%$ for atypical hyperplasia, $100 \%$ for adenocarcinoma, and $71 \%$ for phase compatible endometrium. ${ }^{19}$ In our study, the accuracy rate of diagnostic curettage was $97.5 \%$ for phase compatible endometrium, $80 \%$ for atrophic endometrium, and $71.4 \%$ for hyperplasia. Our rates were higher than the values reported in the literature which is a result that can be attributed to the fact that we did not separately analyze the subgroups of phase compatible endometrium and hyperplasia groups.

There are many studies in the literature which discuss whether routinely applying diagnostic curettage before hysterectomy is necessary or not. Stovalt et al. note that diagnostic curettage is unnecessary in asymptomatic patients at low risk for malignancy, however, they also point out that it should be performed in cases above 35 years of age and showing abnormal uterine hemorrhage or in patients under 35 years of age and at high risk for malignancy. ${ }^{20}$ In the current study, 222 patients received diagnostic curettage because of being under 35 
years of age and demonstrating abnormal uterine hemorrhage, whereas 4 patients received diagnostic curettage due to presence of postmenopausal hemorrhage. Duplantier et al. noted that applying diagnostic curettage in uterine myoma cases showing no abnormal uterine hemorrhage, would be unnecessary, as well. ${ }^{21}$ Lerner et al. do not recommend diagnostic curettage in cases that are not thought be at high risk for endometrial carcinoma, and in their study, they found the sensitivity and positive predictive value of the procedure as $20 \%$ and $50 \%$, respectively. ${ }^{22}$ In our study, no patient was at high risk for endometrial carcinoma with regard to their medical history, familial history, or physical and gynecologic examination findings. Moller et al. determined malignancy after hysterectomy in $3(0.72 \%)$ of 411 cases and found that 1 of those had been missed by curettage, and thus they did not recommend diagnostic curettage ${ }^{23}$ In the current study, no endometrial malignancy was determined in our 260 cases. In our opinion, this result can be associated with the low study sample.

\section{Conclusion}

In conclusion, we believe that routine diagnostic curettage is not essential with regard to evaluating malignancy and detecting a pathology that would change the surgery plan in uterine myoma cases scheduled for hysterectomy.

\section{References}

1. Blake RE. Leiomyomata uteri: hormonal and molecular determinants of growth. J Natl Med Assoc. 2007 Oct;99(10):117084. PubMed PMID: 17987921; PubMed Central PMCID: PMC2574407.
2. Balcı O, Çolakoğlu M, Özdemir S Benign diseases of the uterine corpus. Turkiye Klinikleri J Surg Med Sci 2007;3(40):27-35.

3. Marshall LM, Spiegelman D, Barbieri $\mathrm{RL}$, Goldman MB, Manson JE, Colditz GA, Willett WC, Hunter DJ. Variation in the incidence of uterine leiomyoma among premenopausal women by age and race. Obstet Gynecol. 1997 Dec;90(6):967-73. PubMed PMID: 9397113.

http://dx.doi.org/10.1016/S0029-

7844(97)00534-6

4. Breech LL, Rock JA. Leiomyomata uteri and myomectomy. Chapter 30. In: Rock JA, Jones HW, editors. Te Linde's Operative Gynecology. 9th ed. Philadelphia: Lippincott Williams \& Wilkins; 2003. P. 753-98.

5. Cramer SF, Patel A. The frequency of uterine leiomyomas. Am J Clin Pathol. 1990 Oct;94(4):435-8. PubMed PMID: 2220671.

6. Maruo T, Ohara N, Wang J, Matsuo H. Sex steroidal regulation of uterine leiomyoma growth and apoptosis. Hum Reprod Update. 2004 MayJun;10(3):207-20. PubMed PMID: 15140868.

http://dx.doi.org/10.1093/humupd/dmh0 19

7. Mosselman S, Polman J, Dijkema R. ER beta: identification and characterization of a novel human estrogen receptor. FEBS Lett. 1996 Aug 19;392(1):49-53. PubMed PMID: 8769313. http://dx.doi.org/10.1016/00145793(96)00782-X

8. Kovács KA, Oszter A, Göcze PM, Környei JL, Szabó I. Comparative analysis of cyclin D1 and oestrogen receptor (alpha and beta) levels in human leiomyoma and adjacent myometrium. Mol Hum Reprod. 2001 Nov;7(11):1085-91. PubMed PMID: 11675476.

http://dx.doi.org/10.1093/molehr/7.11.10 85 
9. Sakaguchi H, Fujimoto J, Aoki I, Tamaya T. Expression of estrogen receptor alpha and beta in myometrium of premenopausal and postmenopausal women. Steroids. 2003 Jan;68(1):11-9. PubMed PMID: 12475719. http://dx.doi.org/10.1016/S0039128X(02)00111-3

10. Enmark E, Gustafsson JA. Oestrogen receptors - an overview. J Intern Med. 1999 Aug;246(2):133-8. PubMed PMID: 10447781.

11. Uyar $Y$, Neşe N, Baytur $Y$, Yıldız $H$, Inceboz Ü, Kandiloğlu A. Bcl-2 antigen and TNF-alfa expressions in myomas. Turkiye Klinikleri J Gynecol Obst 2009;19(5):249-54.

12. Shozu M, Sumitani $H$, Segawa $T$, Yang $\mathrm{HJ}$, Murakami K, Inoue M. Inhibition of in situ expression of aromatase P450 in leiomyoma of the uterus by leuprorelin acetate. J Clin Endocrinol Metab. 2001 Nov;86(11):5405-11. PubMed PMID: 11701714.

http://dx.doi.org/10.1210/jc.86.11.5405

13. Murphy LJ, Ghahary A. Uterine insulinlike growth factor-1: regulation of expression and its role in estrogeninduced uterine proliferation. Endocr Rev. 1990 Aug;11(3):443-53. PubMed PMID: 2226350.

14. Sincan S, Keskin L, Üstüner I, Avşar F. Correlation of preoperative diagnosis and postoperative histopathologic findings in patients operated for presumed leiomyoma and the increased accuracy rate in preoperative diagnose. Turkiye Klinikleri J Gynecol Obst 2011;21(2):89-93.

15. Gökaslan H, Pekin T, Ay Z, Kavak Z, Eren $F$. Smooth muscle tumors of the uterus. Turkiye Klinikleri J Gynecol Obst 2004; 14(1):27-31
16. Fraser IS, Critchley HO, Munro MG, Broder M; Writing Group for this Menstrual Agreement Process. A process designed to lead to international agreement on terminologies and definitions used to describe abnormalities of menstrual bleeding. Fertil Steril. 2007 Mar;87(3):466-76. Erratum in: Fertil Steril. 2007 Aug;88(2):538. PubMed PMID: 17362717.

http://dx.doi.org/10.1016/j.fertnstert.200 7.01 .023

17. Bettocchi S, Ceci O, Vicino M, Marello F, Impedovo L, Selvaggi L. Diagnostic inadequacy of dilatation and curettage. Fertil Steril. 2001 Apr;75(4):803-5. PubMed PMID: 11287038. http://dx.doi.org/10.1016/S00150282(00)01792-1

18. Epstein E, Ramirez A, Skoog L, Valentin L. Dilatation and curettage fails to detect most focal lesions in the uterine cavity in women with postmenopausal bleeding. Acta Obstet Gynecol Scand. 2001 Dec;80(12):1131-6. PubMed PMID: 11846711.

http://dx.doi.org/10.1034/j.16000412.2001.801210.x

19. Hakverdi S, Güngören A, Hakverdi $A$, Dolapçıŏlu K, Çiftçi Ş, Kaya Z, et al. Diagnostic value of dilatation and curettage to detect intrauterine lesions in women with abnormal uterine bleeding. J Turk Soc Obstet Gynecol 2008;5(3):202-6.

20. Stovall TG, Solomon SK, Ling FW. Endometrial sampling prior to hysterectomy. Obstet Gynecol. 1989 Mar;73(3 Pt 1):405-9. Erratum in: Obstet Gynecol 1989 Jul;74(1):105. PubMed PMID: 2915864.

21. Duplantier N, Finan MA, Barbe $T$. Necessity of endometrial biopsy in women with enlarged uteri and a preoperative diagnosis of uterine leiomyomata. J Reprod Med. 2003 Jan;48(1):23-7. PubMed PMID: 12611090 . 
22. Lerner HM. Lack of efficacy of prehysterectomy curettage as a diagnostic procedure. Am J Obstet Gynecol. 1984 Apr 15;148(8):1055-6.

PubMed PMID: 6711638.
23. Møller LM, Berget A. Prehysterectomy curettage in women with uterine fibromyomata is not worthwhile. Acta Obstet Gynecol Scand. 1993 Jul;72(5):374-6. PubMed PMID: 8392269.

http://dx.doi.org/10.3109/000163493090 21116 